\title{
Biofuel, Sugar Content, Grain Yields and Qualities of Two Sorghum bicolor in Responses to Levels and Timing of Nitrogen Applications
}

\author{
A. A.A. Mekdad", S.M. Emam \\ Department of Agronomy, Faculty of Agriculture, Fayoum University, Fayoum, Egypt.
}

$\mathbf{T}$

WO FIELD experiments were conducted during the 2017 and 2018, the objective of this work was to evaluate two sweet sorghum varieties under the effect of three nitrogen levels and two different timing of nitrogen application on plant characteristics, quality and yield traits of sweet sorghum. The experimental design was a split-split plot in RCBD with three replications. The main plots were assigned to sweet sorghum varieties viz., Brandes $\left(\mathrm{V}_{1}\right)$ and Honey $\left(\mathrm{V}_{2}\right)$. The subplots were occupied with three levels of nitrogen $80\left(\mathrm{~N}_{1}\right), 100\left(\mathrm{~N}_{2}\right)$ and 120 $\left(\mathrm{N}_{3}\right)$. Two nitrogen applications times viz., at two equal doses $\left(\mathrm{T}_{1}\right)$ and at three equal doses $\left(\mathrm{T}_{2}\right)$ were arranged in the sub-subplots treatments.

Recapitulating our results indicated that nitrogen fertilizer levels and timing of nitrogen application had a highly significant $(\mathrm{P} \leq 0.01)$. Moreover, varieties differed significantly $(\mathrm{P} \leq$ $0.05)$ positive effect on yield and yield components traits in both seasons. The grain yield (1.12 and $1.28 \mathrm{ton} / \mathrm{fed}$, fed $=4200 \mathrm{~m}^{2}=0.405$ hectare) in each seasons, were obtained by Brandes variety $\left(\mathrm{V}_{1}\right)$ with $120 \mathrm{~N} \mathrm{~kg} \mathrm{fed}^{-1}\left(\mathrm{~N}_{3}\right)$ and $T_{2}$ (third equal doses of nitrogen application).

The obtained results of regression analysis of theoretical ethanol yield clarified that, there were three traits, i.e. the sucrose $\%$, the stalk yield and the juice weight in the first year, while in the second year, six traits, i.e. the sugar yield, the sucrose $\%$, the stalk yield, the brix $\%$, the juice extraction $\%$ and juice weight were significantly $(\mathrm{P} \leq 0.001)$ contributed to variation in the theoretical ethanol yield per feddan.

Keywords: Sorghum bicolor, Varieties, Nitrogen levels, Times split nitrogen and ethanol yield. Note: The feddan is a recognized and approved unit in our region and is equal to $4200 \mathrm{~m}^{2}=$ 0.405 hectare)

\section{Introduction}

The sweet sorghum (Sorghum bicolor (L.) Moench), is estimated a potential bioenergy crop and promising multipurpose crop, classified as sweet, grain and forage types, which grow in arid and semiarid regions, and is a leading contender for biofuel production (Nuessly et al., 2013 and Viator et al., 2015). It has many good traits, such as a resistance of drought, water deficiency and salinity. In addition, is represented as higher biomass and sugar content. In arid and semiarid environments, including Egypt, low soil fertility and limited rainfall have reduced crop productivity.

The productivity and its quality of the sweet sorghum are greatly influenced by many factors. Varieties chosen were one of the widely substantial decisions. There is a great difference among sorghum the varieties in stem dimension, yield and its components (Mekdad \& El-Sherif, 2016 and Rady \& Mekdad, 2016). So, it has shining chance and efforts are required for creating and identifying the varieties, having higher sugar content and higher ethanol production potential. Silva et al. (2018) tested two sweet sorghum varieties (BRS 506 and SF 15), reported that first one had the higher leaves number, total chlorophyll (Chlor. total) and they found that the same variety is the best for cultivation in Brazil with useful agronomic traits.

As known, the nitrogen is an essential element, for plants growth and it is still one of the major factors limiting crop yield. Utilization of the nitrogen enhanced sugar percentage, stalks and

\#Corresponding author email: aam07@fayoum.egu.eg

DOI: 10.21608/agro.2019.10075.1152

C2019 National Information and Documentation Center (NIDOC) 
sugar yield in the sweet sorghum plants (Mekdad \& El-Sherif, 2016). Increasing the nitrogen element enhances significantly yield and quality of Beta vulgaris plants (Mekdad, 2015), as well as in sweet sorghum (Mekdad \& El-Sherif, 2016). Almodares \& Hoseini (2016) and Mekdad \& El-Sherif (2016) reported that, the effect of nitrogen levels on stem dimension of (Sorghum bicolor (L.) Moench) was significant, as well as produce the higher values of stem fresh weight, sugar and ethanol yield.

The nitrogen timing at suitable crop growth period, is very important, to enhance the nitrogen use efficiency and increase of the productivity of sweet sorghum. Not all nitrogen applied, is absorbed by the crop since leaching, and is one of the fundamental challenges for nitrogen loss. The nitrogen applied of $92 \mathrm{~kg} / \mathrm{ha}$ at time of $10-15,35-$ 40 and 55-60 days after planting, gave the optimum grain yield Abebe \& Feyisa (2017). Levels and time of nitrogen application are considered among the central abiotic factors, limiting the productivity of the crop. Castilo et al. (1992) studied the effect of nitrogen timing, on the yield of rice. They proved that the superiority of the early nitrogen application, as compared with a late one on the straw yield. Grain and stover yield as well as 1000seed weight (Melaku et al., 2017).

Therefore, the goal of this study was to evaluate, the response of two varieties of sweet sorghum, to an optimum level and time of the nitrogen application, to increase optimum profitable yield under arid conditions.

\section{Materials and Methods}

The present investigation was carried out at the farm of the Faculty of Agriculture, Demo $\left(29^{\circ} 17^{`} \mathrm{~N}\right.$; 30 $\left.33^{`} \mathrm{E}\right)$, Fayoum University, Egypt, during the 2017 and 2018. The experimental soil was sandy loam with organic matter of $0.71 \%$, the electrical conductivity of $3.54 \mathrm{dS} / \mathrm{m}$ and $\mathrm{pH}$ of 7.21 . The objective of this work was to evaluate, two sweet sorghum varieties viz., Brandes and Honey under the effect of three nitrogen levels and two different timing of nitrogen application, on plant characteristics, quality and yield traits of the sweet sorghum. The experiment was set up according to three-factorial (Split-plot plot) block design, in three replications, with the basic plot size of $10.5 \mathrm{~m}^{2}$ , each experimental basic unit included 5 ridges, $60 \mathrm{~cm}$ apart and $3.5 \mathrm{~m}$ long, (1/400fed., fed $=4200$ $\mathrm{m}^{2}=0.405$ hectare). The main plots were assigned to varieties viz., Brandes $\left(\mathrm{V}_{1}\right)$ and Honey $\left(\mathrm{V}_{2}\right)$. The subplots were occupied with three levels of the nitrogen (ammonium nitrate, $\mathrm{NH}_{4} \mathrm{NO}_{3}(33.5 \%$ $\mathrm{N})$ at the level of $80\left(\mathrm{~N}_{1}\right), 100\left(\mathrm{~N}_{2}\right)$ and $120\left(\mathrm{~N}_{3}\right)$. Two nitrogen application times viz., at two equal doses $\left(T_{1}\right)=1 / 2 \mathrm{~N}$ at 15 and $1 / 2 \mathrm{~N}$ at 30 days after planting and at three equal doses $\left(\mathrm{T}_{2}\right)=1 / 3 \mathrm{~N}$ at 15 , $1 / 3 \mathrm{~N}$ at 30 and $1 / 3 \mathrm{~N} 45$ days after planting were arranged in the sub-subplots treatments. Potassium sulphate $\left(48 \% \mathrm{~K}_{2} \mathrm{O}\right)$ applied to the soil in granular form at $50 \mathrm{~kg} \mathrm{~K}_{2} \mathrm{SO}_{4}$ (fed) and applied in two equal doses i.e., after thinning and before the second irrigation (surface irrigation as recommended). Calcium super phosphate $\left(15.5 \% \mathrm{P}_{2} \mathrm{O}_{5}\right)$ at a rate of $200 \mathrm{~kg} /$ fed was applied during land. Seedlings were thinned at two plants/hill, after 21 days from sowing. Other cultural practices such as hoeing, irrigation, etc., were maintained aimed at levels to assure optimum production. The preceding winter crop was sugar beet (Beta vulgaris, L) in both seasons. After sterilization using 1\% (v/v) sodium hypochlorite, experiments were sown on May $7^{\text {th }}$ and $5^{\text {th }}$ in the first and second season and harvest was at dough to the ripe stage (on August 29 $9^{\text {th }}$ and $26^{\text {th }}$ ) in the 2017 and 2018 seasons, respectively.

At harvest time, a random sample of twenty plants from each sub-subplot was taken to determine the following traits. Growth traits: Stem length, stem diameter, stem weight, leaf weight and seed index. Juice quality traits: Stems was taken from each sub-subplot stripped, cleaned and squeezed by electric roller pilot mill. Brix\%: estimated by using a digital refractometer, sucrose $\%$ determined by using direct polarization method as described by A.O.A.C (1995), purity \%: Calculated by dividing sucrose $\%$ / T.S.S\% x100, juice extraction $\%$ : Determined by dividing juice weight/stem weight x 100. Yield and its components: Net stripped stem, leaves, grain, sugar and juice yield, the theoretical ethanol yield $\left(1 \mathrm{fed}^{-1}\right)$ was calculated according to a method described by Lipinski (1978), the ethanol yield $=$ sugar content $($ brix $\%) \times 6.5$ (converting index) $\times 0.85$ (producing index) $\times$ fresh biomass $(\mathrm{t}$ $\mathrm{fed}^{-1}$ ). Where: Converting index is constant (6.5) to explain the efficiency of converting the sugar and biomass of stem yield of the sweet sorghum to ethanol. Producing index is constant $(0.85)$ to explain the efficiency of manufacturing sugar and biomass of stem yield of sweet sorghum to ethanol.

All obtained data were statistically analyzed according to the technique of analysis of variance (ANOVA) for the split-split plot design as published 
by Gomez \& Gomez (1984), using GenStat $12^{\text {th }}$ edition. Least Significant Difference (LSD) method was used to test the differences between treatment means at 5 and $1 \%$ level of probability.

\section{Results and Discussion}

\section{Effect of sweet sorghum varieties}

The results in Tables 1-3 indicated that the two varieties significantly differed at $5 \%$ in regards to the stalk diameter and weight, the ear length and weight, the sucrose $\%$, the juice weight and extraction, as well as the yield in terms of stalk, the leaves, the grain, the sugar, the juice and theoretical ethanol in both season of the experimental. In the 2017 season, varieties significantly differed in the leaves weight and seed index, while brix in the 2018. Conversely, the two varieties had no significantly differed regarding in the stalk height and purity in the 2017 and 2018 seasons. The Brandes $\left(\mathrm{V}_{1}\right)$ variety, presented the highest mean values of former traits, as compared with the anther variety Honey $\left(\mathrm{V}_{2}\right)$. The differences in these traits between varieties might be due to the differences in their genetic the make-up.

Such data, are in the same trend with Mohamed et al. (2006), EL-Sheikh et al. (2011), Mekdad \& El-Sherif (2016) and Ekefre et al. (2017). The superiority of Brandes variety in the theoretical ethanol yield (L/fed) and the sugar yield (ton/fed) in the two seasons might be due to its high records of sucrose mean, brix, the juice extraction and stalks yield.

It was observed that, variety of Brandes (V1) has significantly increases in the stalk diameter $(\mathrm{cm})$ by 10.24 and $10.04 \%$, the stalk weight ( $\mathrm{kg} /$ plant) by 26.60 and $24.58 \%$, ear length $(\mathrm{cm})$ by 13.45 and $13.48 \%$, ear weight $(\mathrm{g})$ by 4.53 and $29.17 \%$, the sucrose $\%$ by 8.96 and $8.62 \%$, the juice weight (kg) by 31.87 and $29.39 \%$, the juice extraction $\%$ by 4.31 and $4.15 \%$, the stalk yield (ton/fed) by 8.31 and $14.43 \%$, the leaves yield (ton/fed) by 30.52 and $26.47 \%$, grain yield (ton/fed) by 27.15 and $39.78 \%$, juice yield (ton/fed) by 12.93 and $19.11 \%$, sugar yield (ton/fed) by 17.32 and $24.81 \%$ and theoretical ethanol (L/fed) by 17.49 and $23.86 \%$ across two seasons, respectively, compared with variety of Honey $\left(\mathrm{V}_{2}\right)$. Our results reported that, thicker and heavier values of variety Brandes $\left(\mathrm{V}_{1}\right)$ stalks could have higher stalks juice and sugar yield and consequently gave the higher values of theoretical ethanol yield. Meantime, the change among verities of sweet sorghum ability in ethanol yield detected herein was confirmed previously by Almodares \& Goli (2013) and Mekdad \& El-Sherif (2016).

\section{Effect of nitrogen fertilization}

Results in Tables 1-3 indicated that, nitrogen fertilizer levels exerted significant effects at the level of $1 \%$ on all traits under studied such as, the stalk and the ear dimension, the weight of stalk, the leaves and ear, the seed index, the percentage of brix, sucrose and purity, the juice weight and extraction, as well as, yield in terms of the stalk, the leaves, the grain, the juice, the sugar and the theoretical ethanol in both seasons.

The highest values of the stalk height (4.22 and $4.21 \mathrm{~cm})$, the stalk diameter $(2.95$ and $2.90 \mathrm{~cm})$, the stalk weight (1146.53 and $1171.30 \mathrm{~g} / \mathrm{plant})$, the leaves weight (225.17 and $213.26 \mathrm{~g} /$ plant), the ear length (34.76 and $33.78 \mathrm{~cm}$ ), the ear diameter $(9.93$ and $10.05 \mathrm{~cm})$, the ear weight $(138.48$ and $132.11 \mathrm{~g} /$ plant), the seed index (31.79 and $41.34 \mathrm{~g})$, as well as the brix (16.55 and $16.69 \%$ ), the sucrose (9.54 and $9.59 \%$ ), the purity ( 57.59 and $57.47 \%$ ), the juice weight $(448.50$ and $459.90 \mathrm{~g})$, the juice extraction (39.02 and 39.20\%) furthermore, the stalk yield (24.41 and 25.62ton/fed), the leaves yield (4.85 and 4.70ton/fed), the grain yield (1.50 and $1.48 \mathrm{ton} / \mathrm{fed})$, the sugar yield (1.58 and $1.68 \mathrm{ton} /$ fed), the juice yield ( 9.53 and 10.05 ton/fed) and finally the theoretical ethanol yield (1287.21 and $1359.92 \mathrm{~L} / \mathrm{fed}$ ) in the first and second season, respectively, were produced from fertilizing sweet sorghum plants with $120 \mathrm{~kg} \mathrm{~N} /$ fed $\left(\mathrm{N}_{3}\right)$. On the contrary, the lowest values of pervious traits were obtained from $60 \mathrm{~kg} \mathrm{~N} / \mathrm{fed}\left(\mathrm{N}_{1}\right)$ in the two growing seasons. Almodares et al. (2008), Usofzadeh et al. (2013), Mekdad \& El-Sherif (2016) and Harshlata $\&$ Sai (2018) reported that increasing the nitrogen fertilization increased stalk height and the stalk diameter, as well as the stalk, the sugar, the juice and the theoretical ethanol yield. Furthermore, concerning the positive effect of nitrogen application on sugar beet Mekdad (2015) and Mekdad \& Rady (2016) reported that increasing nitrogen fertilizer levels increased significantly the productivity of sugar beet. The increase in pervious traits due to nitrogen application can be explained through the fact that nitrogen element has an essential role in building up metabolites, activating enzymes and enhanced stalk dimension as well as stalk fresh weight, so consequently higher stalk, juice, sugar and theoretical ethanol yields per unit area. 


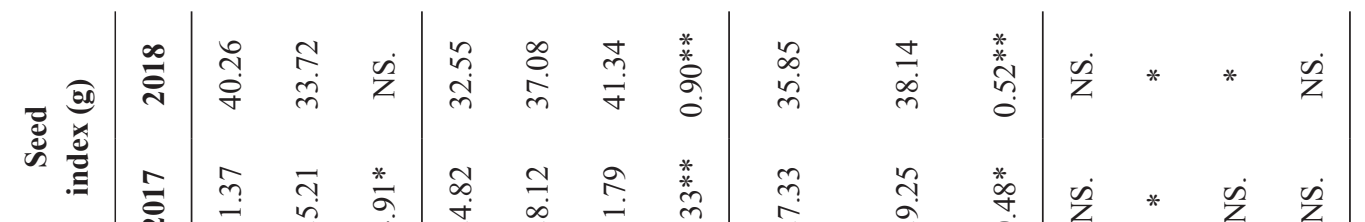

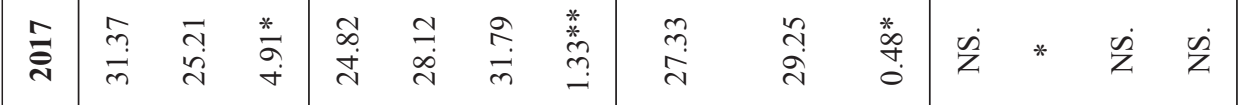

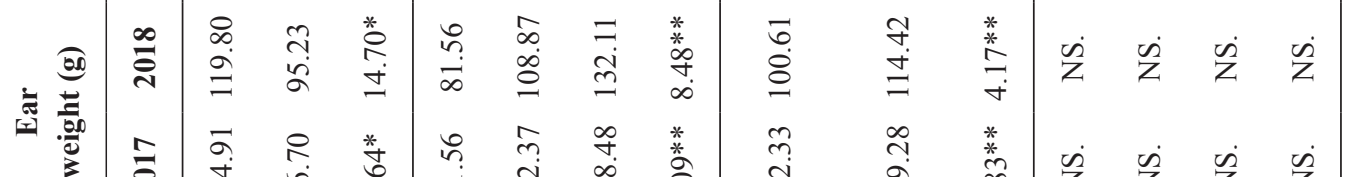

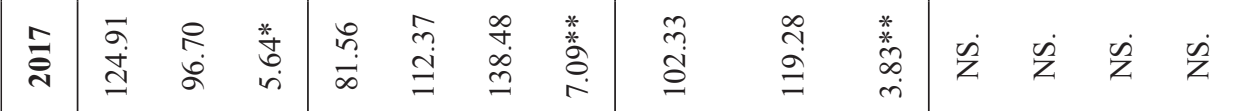

$$
\begin{aligned}
& \text { 竞 }
\end{aligned}
$$

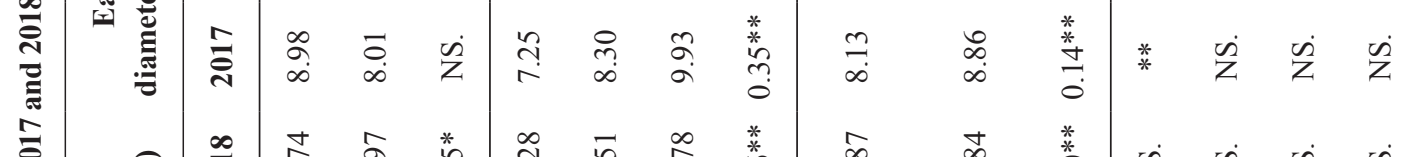

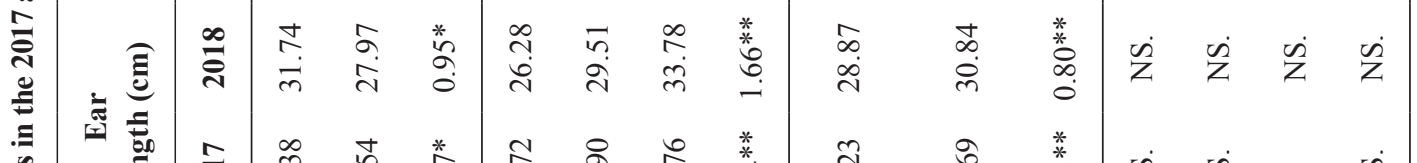

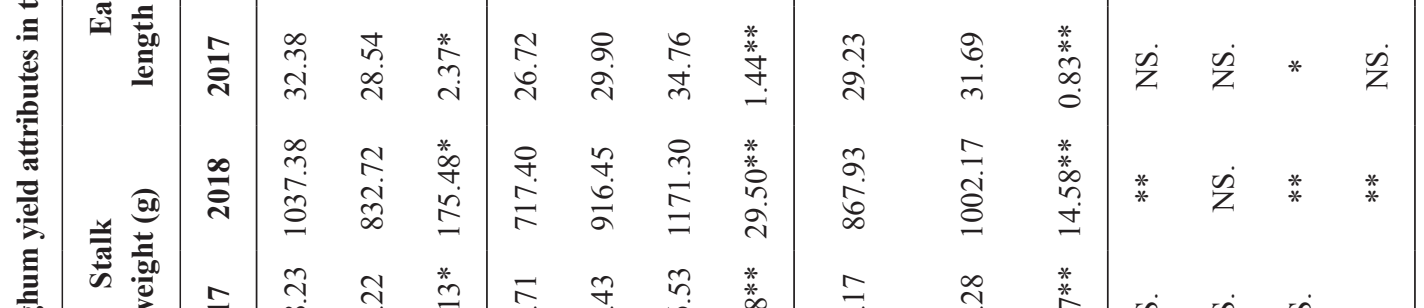

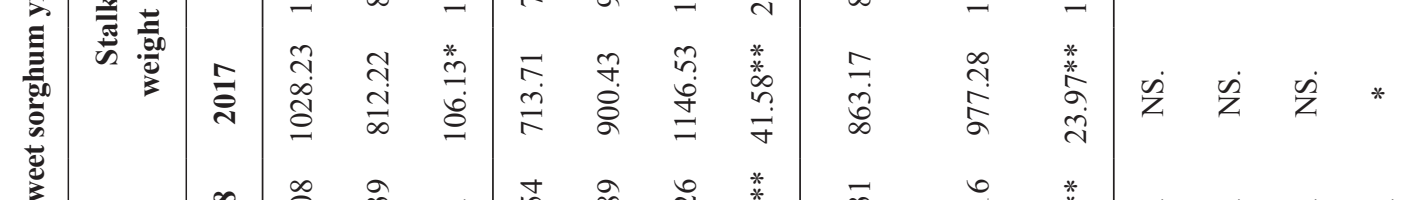

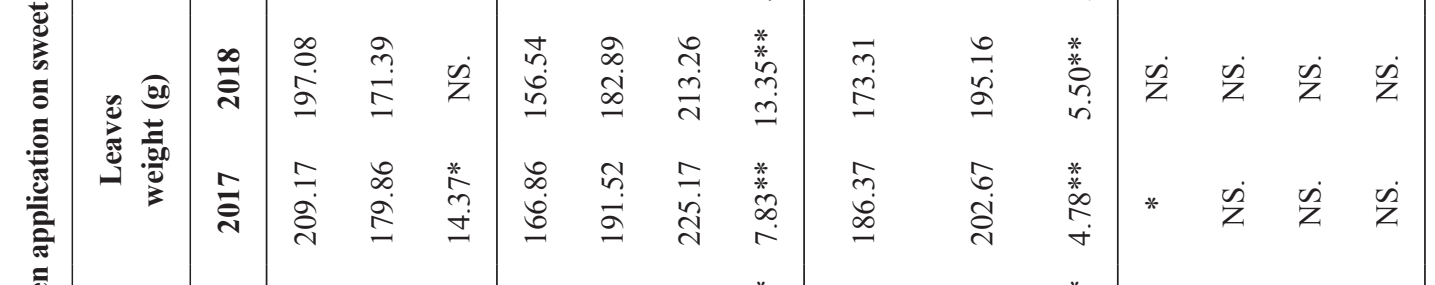

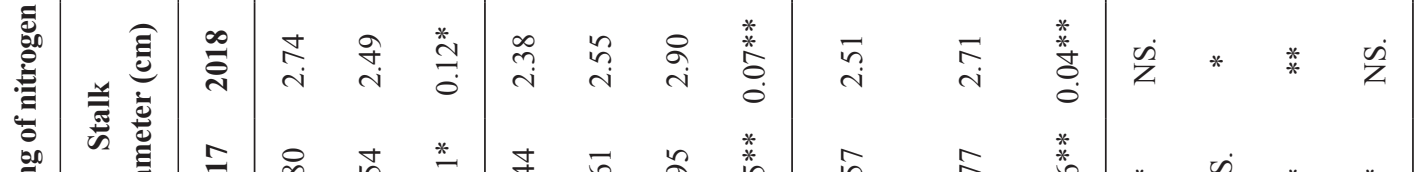

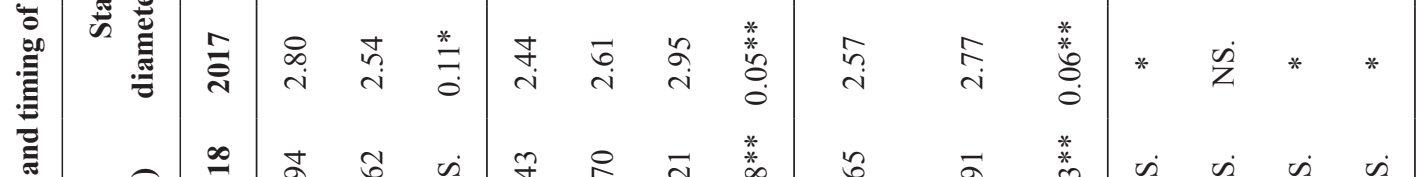

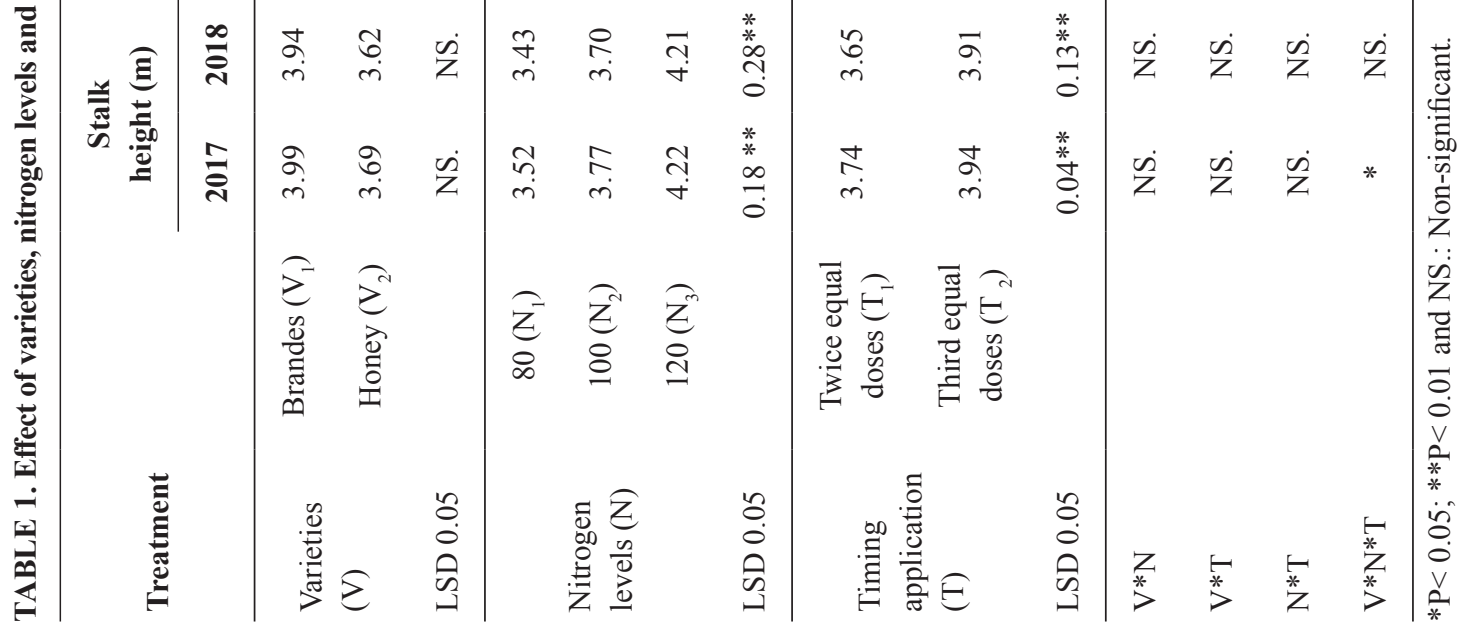

Egypt. J. Agron. 41, No.2 (2019) 


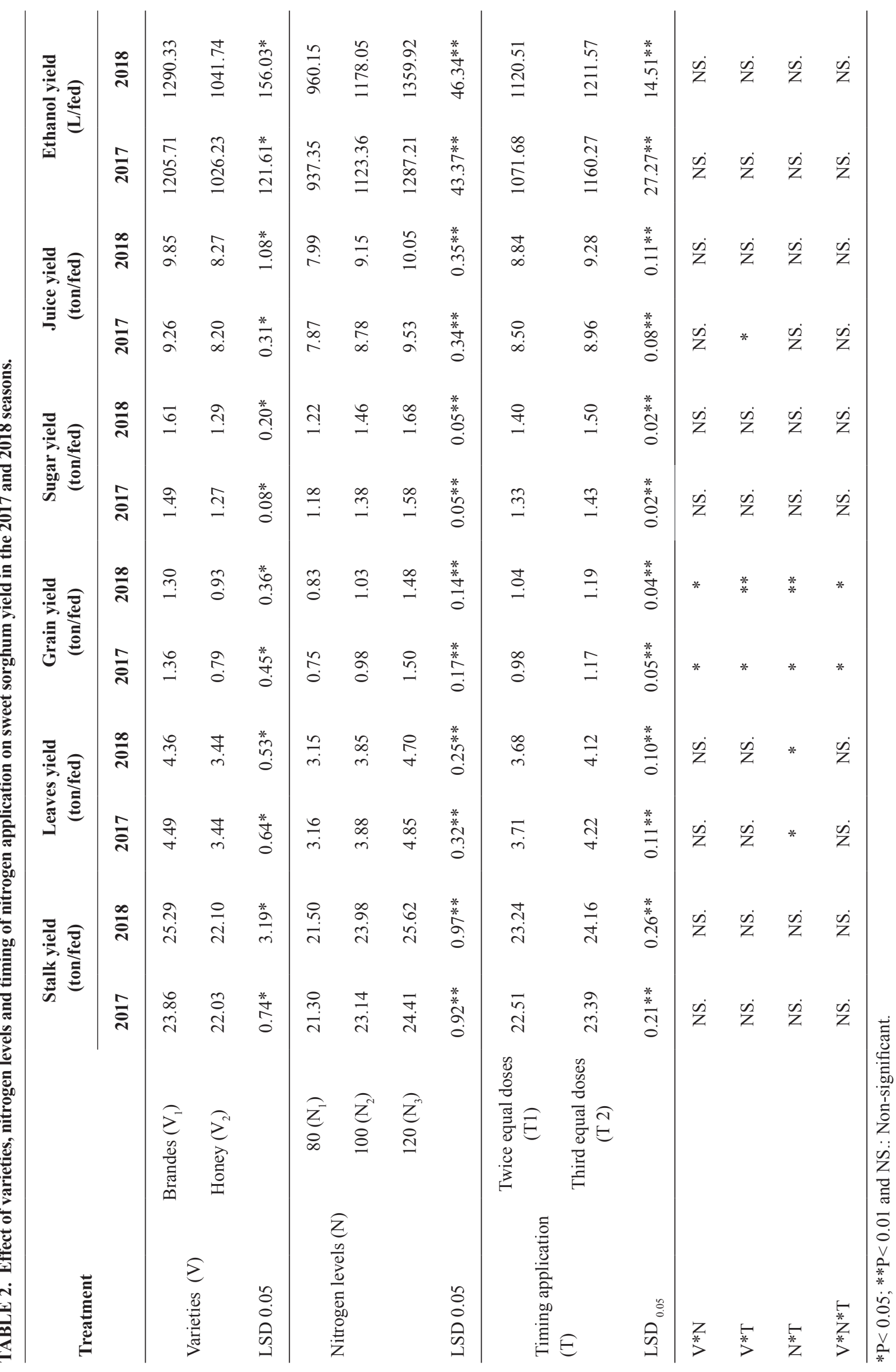




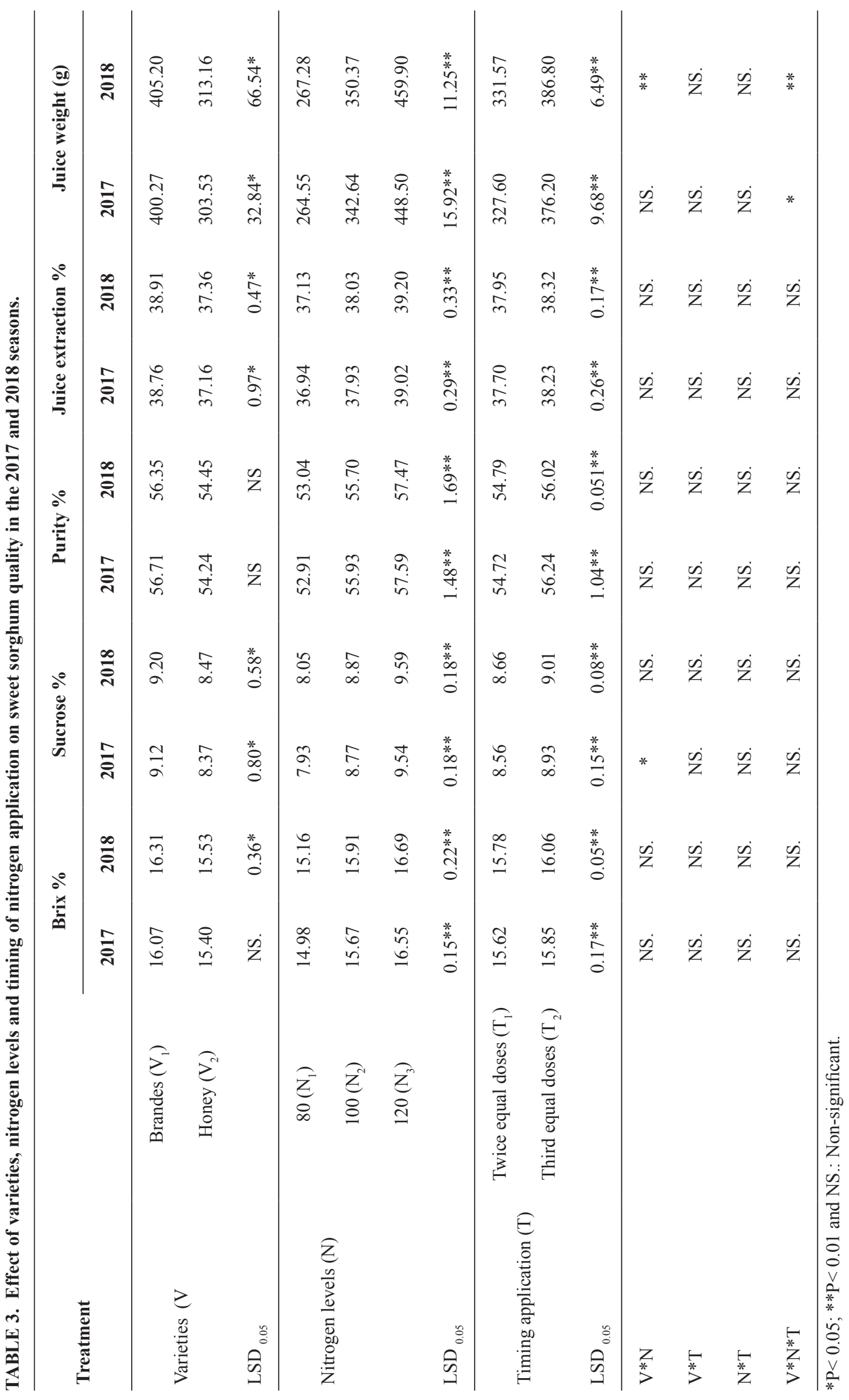

Egypt. J. Agron. 41, No.2 (2019) 


\section{Effect of nitrogen timing application}

Application of nitrogen timing significant differed at $1 \%$ across both seasons (Tables 1-3). The taller stalk (3.94 and $3.91 \mathrm{~m})$, the thicker stalk $(2.77$ and $2.71 \mathrm{~cm})$, the heaver stalk $(977.28$ and $1002.17 \mathrm{~g} / \mathrm{plant})$, the heaver leaves (202.67 and $195.16 \mathrm{~g} /$ plant $)$, the taller ear $(31.69$ and $30.84 \mathrm{~cm})$, the thicker ear $(8.86$ and $8.92 \mathrm{~cm})$, the heaver ear (119.28 and $114.42 \mathrm{~g})$, the higher seed index $(29.25$ and $38.14 \mathrm{~g}$ ), the higher brix (15.85 and $16.06 \%$ ), the higher sucrose (8.93 and $9.01 \%)$, the higher purity (56.24 and $56.02 \%$ ), the heaver juice ( 376.20 and $386.80 \mathrm{~g} / \mathrm{plant}$ ), the higher juice extraction (38.23 and $38.32 \%$ ), as well as, the higher stalk yield (23.39 and 24.16ton/fed), the higher leaves yield (4.22 and 4.12ton/fed), the higher grain yield (1.17 and 1.19ton/fed), the higher juice yield (8.96 and 9.28 ton/fed), the higher sugar yield (1.43 and 1.50 ton/fed) and finally the higher theoretical ethanol yield $(1160.27$ and $1211.57 \mathrm{~L} / \mathrm{fed})$ in the 2017 and 2018 seasons, respectively, were obtained at third equal doses of the nitrogen application $\left(\mathrm{T}_{2}\right)=1 / 3 \mathrm{~N}$ at $15,1 / 3 \mathrm{~N}$ at 30 and $1 / 3 \mathrm{~N} 45$ days after planting. However, on the other hand, the lower pervious traits were obtained at the twice equal nitrogen doses $\left(T_{1}\right)=1 / 2 \mathrm{~N}$ at 15 and $1 / 2 \mathrm{~N}$ at 30 days after planting.

According to Mohammad et al. (2011) in wheat crop, Tilahun et al. (2013) in rice crop and Yohanna (2014) in the sweet sorghum crop reported that, nitrogen timing application had significantly effect on the yield and yield components. To sum up, split nitrogen application, gave the heaviest grain yield. Split application of the nitrogen fertilizer timing at twice doses, increase in grain yield of sorghum over a single dose. Generally, in this work, split application nitrogen timing at third equal doses $\left(\mathrm{T}_{2}\right)=1 / 3 \mathrm{~N}$ at $15,1 / 3 \mathrm{~N}$ at 30 and $1 / 3 \mathrm{~N} 45$ days after planting, resulted in good performance than split nitrogen timing was applied at twice equal doses $1 / 2 \mathrm{~N}$ at 15 and $1 / 2 \mathrm{~N}$ at 30 days after planting and mitigate the loss of nutrients by leaching.

\section{Interaction effects}

Effect of the bilateral interaction between the two sweet sorghum varieties and tree nitrogen levels

Recapitulating our results showed in Table 4 reported that, the mean values of the ear diameter $(10.06$ and $10.70 \mathrm{~cm})$ and the grain yield $(1.95$ and $1.78 \mathrm{ton} / \mathrm{fed})$ in both season, as well as the stalks diameter $(3.12 \mathrm{~cm})$, the leaves weight $(246.71 \mathrm{~g})$ and the sucrose $(9.82 \%)$ in the first season, furthermore the stalk weight $(1254.77 \mathrm{~g})$ and the juice weight $(499.09 \mathrm{~kg})$ in the second season were significantly affected by the interaction. The highest means values of former traits, were recorded by Brandes variety $\left(\mathrm{V}_{1}\right)$ with the highest nitrogen level application $\left(\mathrm{N}_{3}\right) 120 \mathrm{~kg} \mathrm{~N} /$ fed. Reddy et al. (2008) and Mekdad \& El-Sherif (2016) reported that, the interaction between nitrogen levels fertilizer and varieties were significant for stalk weight (kg/plant), sucrose \%, juice extract $\left(\mathrm{gm}^{-2}\right)$ and sugar yield (ton ha ${ }^{1}$.

Effect of the bilateral interaction between the two sweet sorghum varieties and two timing of nitrogen application

To sum up, data illustrated in Table 5 reveal that, the values means of the seed index (32.56 and $41.66 \mathrm{~g})$ and the grain yield (1.48 and $1.40 \mathrm{ton} / \mathrm{fed})$ in both seasons, the juice yield (9.44ton/fed) in the 2017 season, as well as stalk diameter $(2.86 \mathrm{~cm})$ in the 2018 season were significantly affected by the interaction. The highest mean values of former traits, were recorded by Brandes variety $\left(\mathrm{V}_{1}\right)$ of sweet sorghum with the times of nitrogen application at third doses $\left(\mathrm{T}_{2}\right)=1 / 3 \mathrm{~N}$ at $15,1 / 3 \mathrm{~N}$ at 30 and $1 / 3 \mathrm{~N} 45$ days after planting.

Effect of the bilateral interaction between three nitrogen levels fertilization and two timing of nitrogen application

Nitrogen levels by timing of nitrogen application, showed significant effects on the stalk diameter $(3.11$ and $3.07 \mathrm{~cm})$, the leaves yield ton/ fed (5.20 and 4.99ton) and the grain yield (1.65 and $1.63 \mathrm{ton} / \mathrm{fed}$ ) in each season, as well as the ear length $(36.84 \mathrm{~cm})$ in the first season, furthermore the stalk weight $(1256.20 \mathrm{~g})$ and the seed index (42.96g) in the second season of sweet sorghum varieties (Table 6), were obtained by the higher of nitrogen levels $\left(\mathrm{N}_{3}\right) 120 \mathrm{~N} \mathrm{~kg} \mathrm{fed}^{-1}$ and $T_{2}$ (split nitrogen times application at third equal doses $=1 / 3 \mathrm{~N}$ at 15 , $1 / 3 \mathrm{~N}$ at 30 and $1 / 3 \mathrm{~N} 45$ days after planting) (Table 6 ). These results are in agreement with those showed by Melaku et al. (2017) in sweet sorghum yield and Abebe \& Feyisa (2017) in Zea mays L. yield.

Effect of the trilateral interaction among the two sweet sorghum varieties, three levels of nitrogen fertilizer and two timing of nitrogen application

Interaction of varieties and nitrogen levels with the timing of nitrogen also showed significantly effects on the stalk weight (1304.17 and $1289.00 \mathrm{~g}$ ) (Table 7), the juice weight $(521.09$ and $514.55 \mathrm{~g})$ and grain yield (2.18 and 1.99ton/fed) in each seasons, as well as the stalk height $(4.63 \mathrm{~cm})$ and 
the stalk diameter $(3.36 \mathrm{~cm})$ in 2017 season (Table 7), were obtained by Brandes variety $\left(\mathrm{V}_{1}\right)$ with $120 \mathrm{~N} \mathrm{~kg} \mathrm{fed}^{-1}\left(\mathrm{~N}_{3}\right)$ and $T_{2}$ (at third equal nitrogen doses $1 / 3 \mathrm{~N}$ at $15,1 / 3 \mathrm{~N}$ at 30 and $1 / 3 \mathrm{~N} 45$ days after planting) (Table 7).

\section{Yield analysis study \\ Correlation coefficient}

The results of correlation coefficients, in Table 8 between theoretical ethanol yield $\mathrm{L} \mathrm{fed}^{-1}$ and each of stalk weight plant ${ }^{-1} \mathrm{~g}$, yield of stalk, sugar and juice (ton fed ${ }^{-1}$ ), brix, sucrose and juice extraction $\%$ as well as juice weight $(\mathrm{kg})$ were computed, in order to throw light, on the relationship of effectual traits interest. Positive and highly significant $(\mathrm{P} \leq$ $0.01)$ correlations were obtained between ethanol yield $\mathrm{L} \mathrm{fed} \mathrm{d}^{-1}$ and each of juice yield $\left(\mathrm{r}=0.976^{* *}\right.$ and $\left.0.983^{* *}\right)$, sugar yield $\left(\mathrm{r}=0.978^{* *}\right.$ and $\left.0.991^{* *}\right)$ and sucrose $\%\left(\mathrm{r}=0.979^{* *}\right.$ and $\left.0.948^{* *}\right)$. Also, positive and highly significant correlation coefficient were seen between sugar yield $\mathrm{t} \mathrm{fed}^{-1}$ and stalk yield ton $\mathrm{fed}^{-1}$ in $\left(\mathrm{r}=0.949^{* *}\right.$ and $\left.0.974^{* *}\right)$ as well as between brix $\%\left(\mathrm{r}=0.958^{* *}\right.$ and $\left.0.943^{* *}\right)$ in $1^{\text {st }}$ and $2^{\text {nd }}$ seasons, respectively, this result is consistent with the previous researchers of (Rady \& Mekdad, 2016).

According to Stepwise results, in data in Table 9 clarified that, there are three traits, i.e. sucrose, stalk yield and juice weight in the 2017 season and six ones, i.e. sugar yield, sucrose (\%), stalk yield, brix $\%$, juice extraction $\%$ and juice weight in the 2018 season, were significantly $(\mathrm{P} \leq 0.001)$ contributed to variation in theoretical ethanol yield per feddan.

\section{Conclusions}

This study tested the effects of nitrogen levels and timing of the $\mathrm{N}$ application on performances of two sweet sorghum varieties Brandes and Honey. To sum up, 2- Years of study showed that, the highest yield of grain, sugar, juice and theoretical ethanol were obtained by Brandes variety and higher level of nitrogen fertilization at $120 \mathrm{~kg} \mathrm{~N} / \mathrm{fed}$ with split nitrogen times application at third equal doses $(1 / 3 \mathrm{~N}$ at $15,1 / 3 \mathrm{~N}$ at 30 and $1 / 3 \mathrm{~N} 45$ days after planting). Timing of nitrogen applications, can play a basic role, in strategically of nutrient management, which is productivity and environmentally responsible. Timing nitrogen applied, can help farmers improving efficiency of nutrient, increase crop yields and decrease the losses of nutrients by leaching.

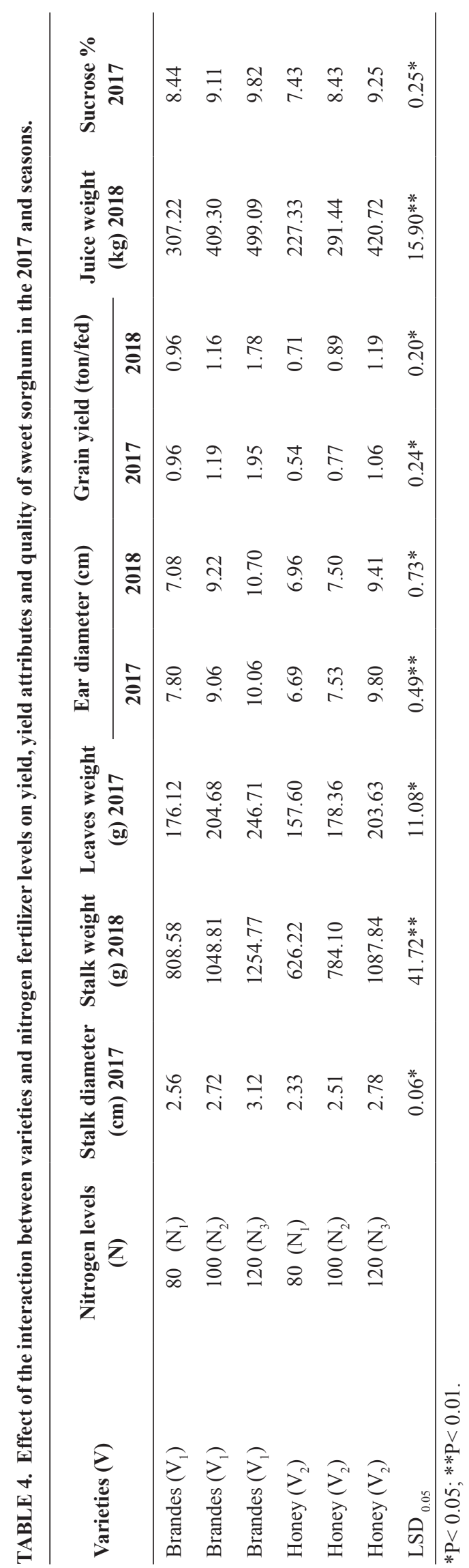




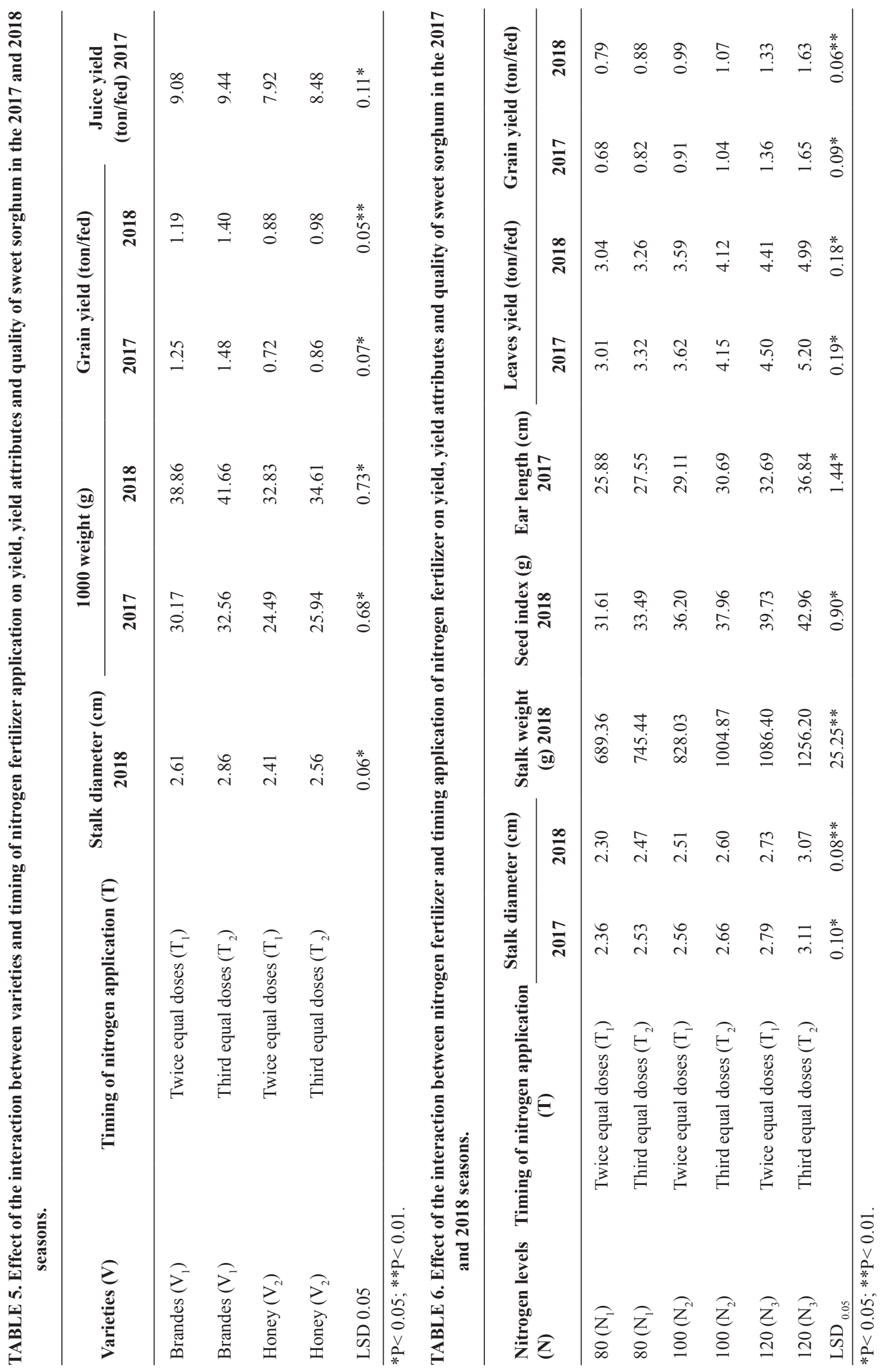

Egypt. J. Agron. 41, No.2 (2019) 

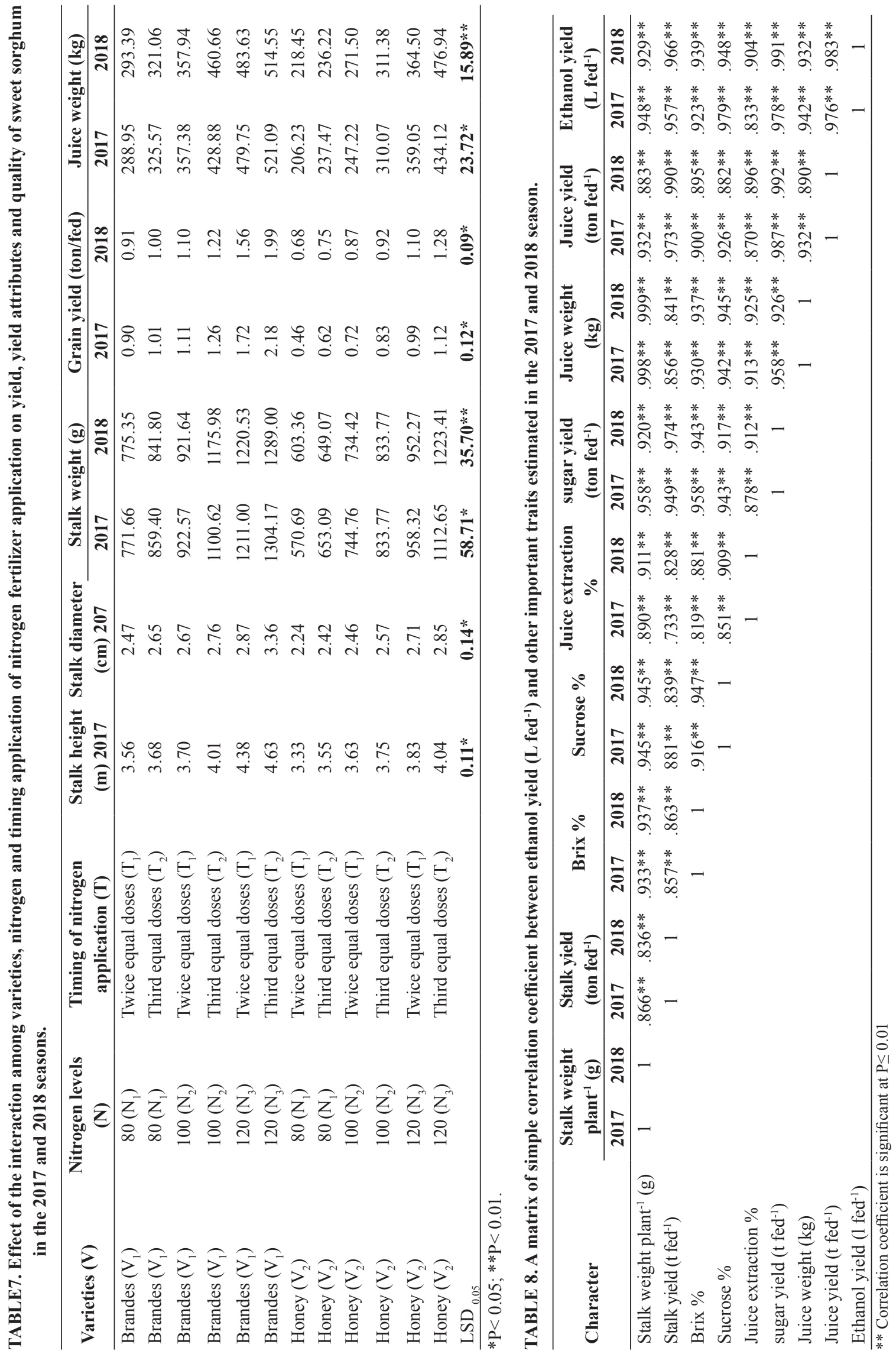

Egypt. J. Agron. 41, No.2 (2019) 
$\underline{\text { References }}$

A.O.A.C. (1995) "Official Methods of Analysis" Published by the A.O.A.C. Box 540, Washington.

Abebe, Z. and Feyisa, H. (2017) Effects of nitrogen rates and time of application on yield of maize: Rainfall variability influenced time of $\mathrm{N}$ application. Int. $J$. of Agron. 1(1), 1-10.

Almodares, A. and Goli, M. (2013) Preliminary study on the effect of plant population density and sweet sorghum cultivars on bioethanol production, Biofuels, 4(2), 163-167.

Almodares, A. and Hoseini, S. H. (2016) Effect of sowing dates and nitrogen levels for ethanol production from sweet sorghum stalks and grains. Afr. J. Agric. Res. 11(4), 266-275.

Almodares, A., Taheri1, R., Chung, I.M. and Fathi, M. (2008) The effect of nitrogen and potassium fertilizers on growth parameters and carbohydrate contents of sweet sorghum cultivars. J. Environ. Biol. 29(6), 849-852.

Castilo, E.G., Buresh R.J. and Ingram, K.T. (1992) Lowland Rice yield as affected by timing of water deficit and nitrogen fertilization. Agron. J. 84, $152-$ 159.

Ekefre, D.E., Mahapatra, A.K., Latimore Jr, M., Bellmer, D.D., Jena, U., Whitehead, G.J. and Williams, A.L. (2017) Evaluation of three cultivars of sweet sorghum as feedstocks for ethanol production in the Southeast United States. Heliyon. 3, 1-18.

EL-Sheikh, S.R.E., EL-Labbody, A.H.S.A. and Osman, A.M.H. (2011) Response of three sweet sorghum varieties to potassium mineral -and bio - fertilization. Egypt. J. Agric. Res. 89(3), 10191027.

Gomez, K.A. and Gomez, A.A. (1984) "Statistical Procedures For Agricultural Research". Book John Willey and Sons Inc., New York.

Harshlata, G.S. and Sai, S. (2018) Effect of planting density and levels of nitrogen on ethanol production of sweet sorghum (Sorghum bicolor [L.] Moench) varieties. The Pharma Innovation J. 7(2), 04-07.

Lipinski, E.S. (1978) Sugar crops as a source of fuels, vol. II. Processing and Conversion, Research Dept. of 
Energy. Final Report. Battelle Columbus Labs, OH.

Mekdad, A.A.A. (2015) Sugar beet productivity as affected by nitrogen Fertilizer and foliar spraying with boron. Int. J. Curr. Microbiol. Appl. Sci. 4(4), 181-196.

Mekdad, A.A.A. and El-Sherif, A.M.A. (2016) The effect of nitrogen and potassium fertilizers on yield and quality of sweet sorghum varieties under arid regions conditions. Int. J. Curr. Microbiol. Appl. Sci. 5(11), 811-823.

Mekdad, A.A.A. and Rady, M.M. (2016) Response of Beta vulgaris $\mathrm{L}$. to nitrogen and micronutrients in dry environment. Plant Soil Environ. 62(1), 23-29.

Melaku, N.D., Bayu, W., Ziadat, F., Strohmeier, S., Zucca, C., Tefera, M.L., Ayalew, B. and Klik, A. (2017) Effect of nitrogen fertilizer rate and timing on sorghum productivity in Ethiopian highland Vertisols. Archives of Agron and Soil Sci. 1(1), 1-12.

Mohamed, K.E., Ferweez, H. and Allam, S.M. (2006) Effect of $\mathrm{K}$ fertilization on yield and quality of sweet sorghum juice and syrup. Bull. Fac. Agric. Cairo Univ. 57, 401-416.

Mohammad, T., Jamal Khan, M.D., Khan, A.D., Arif, M.D., Jan, D.D., Saeed, M.D. and Zahir, M.D. (2011) Improving wheat productivity through source and timing of nitrogen fertilization. J. Bot. 43(2), 909-911.

Nuessly, G.S., Wang, Y., Sandhu, H., Larsen, N. and Cherry, R.H. (2013) Entomologic and agronomic evaluations of 18 sweet sorghum cultivars for biofuel in Florida. Fla. Entomol. 96(2), 512-528.

Rady, M.M. and Mekdad, A.A.A. (2016) Productivity response to plant density in five Sorghum bicolor varieties in dry environments. Egypt. J. Agron. $\mathbf{3 8}$ (3), 531-546.

Reddy, P.S., Reddy, B.V.S., Kumar, A.A. and Rao, P.S. (2008) Standardization of nitrogen fertilizer rate for sugar yield optimization in sweet sorghum. J. SAT Agri. Res. 6, 1-4.

Silva, T.M., Oliveira, A.B., Moura, J.G., Lessa, B.F.T. and Oliveira, L.S.C. (2018) Agronomic evaluation of sweet sorghum in semiarid region: Cultivar and spacing effects. J. Agric. Sci. 10(10), 103-113.

Tilahun, T., Alemayehu, A., Minale, L. and Zelalem, T. (2013) Effects of nitrogen split application on productivity, nitrogen use efficiency and economic benefits of maize production in Ethiopia. Int. J. Agric Policy Res. 1(4), 109-115.

Usofzadeh, M., Daneshvar, M., Almodares, A. and Eisvand, H.R. (2013) Effects of nitrogen fertilizer and plant growth regulator on stalk yield and bioethanol in sweet sorghum. Iranian J. Plant Physiol. 3(3), 711-716.

Viator, H.P., Lu, S. and Aragon, D. (2015) Influence of panicles and leafy material on sweet sorghum juice quality. J. Am. Soc. Sugar Cane Technol. 35, 21-30.

Yohanna, M.K. (2014) Effect of time of nitrogen application on the performance of maize (Zea mays L.) varieties at Mubi, Northern Guinea Savanna of Nigeria. Am. J. Res. Comm. 2(2), 71-81.

(Received 27/ 2/2019; accepted 9/6 /2019) 


\section{إستجابه بعض أصناف الذرة الرفيعة لمستويات ومواعيل إضافة التسميد النيتروجينى لإنتاج الوقود الحيوي والسكر والحبوب التهب على عبدالله على مقداد، صلاح الدين محمد إمام

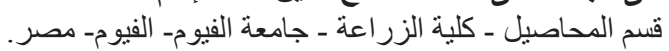

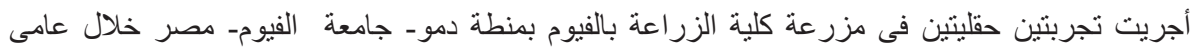

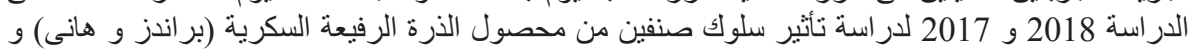

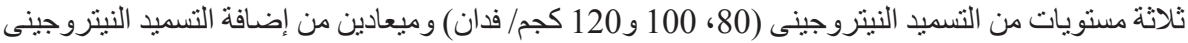

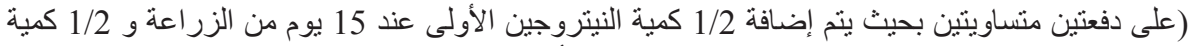

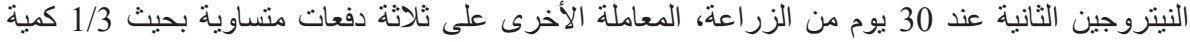

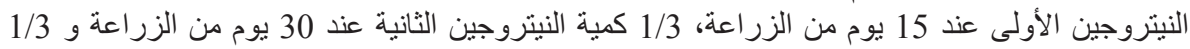

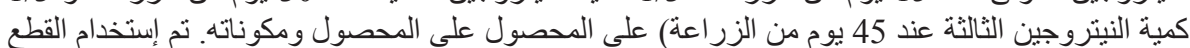

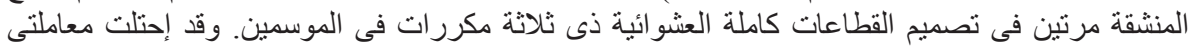

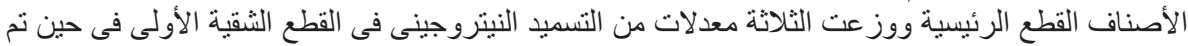

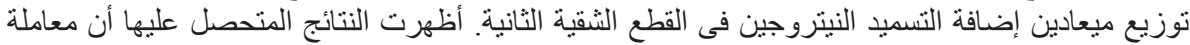

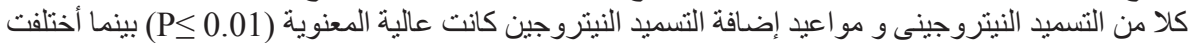

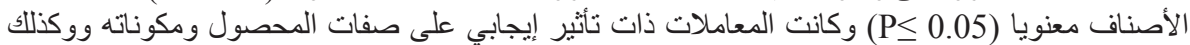
صفات الجودة في كلا الموسمين.

أظهرت النتائج المتحصل عليها أن أعلى وزن للسيقان (1112.62 و و 1223.41 جرام) ووزن وزن العصبر المستخلص (434.12 و 476.94جر ام ) وكذلك محصول الحبوب (1.12 و 1.28 طن طن/فدان) في كلا الموسمين

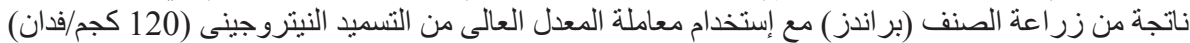

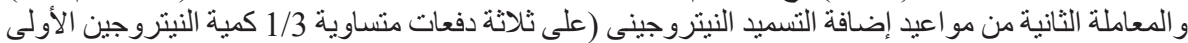

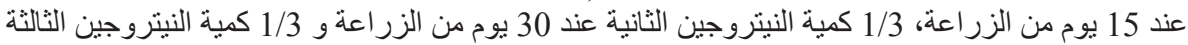

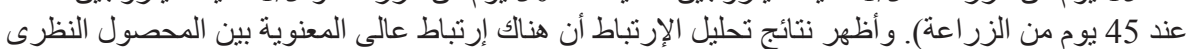

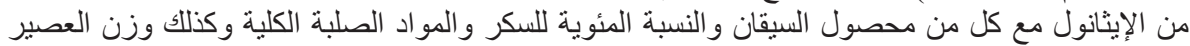

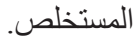

